\title{
An Efficient Protocol for Callus Induction in Aquilaria malaccensis Lam. Using Leaf Explants at Varied Concentrations of Sucrose
}

\author{
Moitre yee Saikia, Karuna Shrivas tava*, S. Sureshkumar Singh \\ Laboratory of Biotechnology \& Plant-Microbe Interaction, Department of Forestry, North Eastern Regional Institute of Science and \\ Technology, Nirjuli, 791109, Arunachal Pradesh, India
}

\begin{abstract}
Aquilaria malaccensis Lam. (Family: Thy melaeaceae), commonly known as agarwood, eagle wood or Gaharu is a co mmerc ially important tree species of northeast India. The Aquilaria tree is categorised as critically endangered in Ind ia. This species is being continuously exploited due to its precious heartwood which is the source of expensive agar oil used in the production of high grade perfumes as well as in traditional medicines. The main aim of this study was to establish a speedy callus production protocol from Aquilaria malaccensis which may serve as an important option for direct extraction of agar oil. For this purpose, large scale production of callus tissue is needed. An efficient callus regeneration protocol was established through leaf pro liferation in Aquilaria malaccensis Lam. using Murashige and Skoog mediu m supplemented with least amount of plant growth hormones $(2,4 \mathrm{D}$, NAA, Kinetin \& BAP) at varied concentrations of sucrose (2-5\%). Callus could be initiated in all the treatments of hormones and sugar levels; however, the best callus growth was obtained in the MS med iu msupple mented with BAP $(0.5 \mathrm{mg} / \mathrm{l})+\mathrm{NAA}(3 \mathrm{mg} / \mathrm{l}) \mathrm{g}$ iving the highest fresh $(7.368 \mathrm{~g})$ and dry cell b io mas s $(2.170 \mathrm{~g})$ at the optimu $\mathrm{m}$ sucrose concentration (4\%) after 45-60 days of incubation.
\end{abstract}

Keywords Agarwood, Callus, Growth hormones, Sucrose concentration

\section{Introduction}

In India, the medium sized evergreen tree Aquilaria malaccensis Lam. (syn. Aquilaria agallocha Ro xb. of family Thymelaeaceae) co mmon ly known as agarwood, eagle wood or Gaharu is confined to Eastern Himalayas up to an altitude of $1000 \mathrm{~m}$. The term 'Agarwood' refers to its res inous heartwood which turns aromatic and highly valuable as a result of infections by a few endophytic fungi[1]. There are fifteen species in the genus Aquilaria of which eight are known to produce agarwood[2]. A. malaccensis is chiefly distributed in 10 countries viz. Bangladesh, Bhutan, India, Indonesia, Iran, Malaysia, Myanmar, Philippines, Singapore and Thailand[3]. In India, it is occurring mainly in Arunachal Pradesh, Assam, Mizoram, Manipur, Nagaland, Sikkim and West Bengal[4]. A. malaccensis is known to be one of the most important species of commerce and valued for production of its impregnated resinous heart wood that gives fragrance [5]. The infected parts of agarwood serve as important raw material in the production of incense,

\footnotetext{
* Corresponding author:

karuna.nerist@gmail.com (KarunaShrivastava) Published online at http://journal.sapub.org/plant

Copyright (C) 2012 Scientific \& Academic Publishing. All Rights Reserved
}

perfumes and traditional med icines[6]. The agar wood oil or aloe wood oil, known in the east as 'agar attar' is obtained by distilling selected parts of the infected wood of Aquilaria sp. which has unique fragrance and high export value[7]. The agar oil traders have to sacrifice whole tree as its heart wood serves as raw materials for oil distillation. Many uninfected or less infected trees are also been destroyed by them in search of agarwood. Due to such exploitation, this tree species is now rarely found in wild habitat and considered as critically endangered in India. Consequently, it is included in IUCN red data list of the year 2011 as vulnerable and at the verge of extinction from the natural forests [8]; hence there is an urgent need to apply modern technologies for the conservation and existence of this particular species as well as for preservation of its germplasm. The application of biotechnological methods such as plant tissue culture technique may be the best alternative for the above purposes. Plant tissue culture is also important for the species which has very short dormancy period and dependent on any particular reproductive period as in case of traditional method of sexual reproduction. The A. malaccensis Lam. also have restricted period of seed viability[9]. The plant is generally propagated through seeds who germinate readily after maturity; however their rate of germination sharply reduces with the increase in the period of storage/decrease in its mo isture contents. Fresh seeds obtained by splitting open 
the capsule showed a short dormancy period ranging from 1 week to 4 weeks only. The maximum germination $(90 \%)$ takes place within 20 days in case of fresh seeds and 7 days for stored seeds with very less germination percentage. Seed weight has a positive influence in germination, plant size, root length and ultimately in yearly plant establishment[9]. The in-vitro propagated medicinal plants furnish a ready source of uniform, sterile and compatible plant material for mass multiplication and help in germplas m conservation of rare, endangered and threatened medicinal plants. Taking these factors into consideration, techniques of plant tissue culture were adopted by many scientists for propagation of Aquilaria seedlings and to supplement the conventional methods of regeneration[10],[11]. By using tissue culture raised agarwood plantlets, growers may obtain more oleores in than those plantlets grown fro m random seeds. The uniform growth with tissue culture plantlets may make the process of inducing oleores in formation easier and volu me of oleoresin more predictable. However; the proper and long-term monitoring of these seedlings is essential for their adaptation in natural conditions and for afforestation and plantation programmes for the socio-economic benefits of local populace.

Agar oil production from callus through plant tissue culture is another option which may be commercially exploited. In-vitro production of agar oil from callus culture of A. agallocha Roxb. and analysis of its chemical constituents by GC/MS have already been done success fully[12]. Chemical analys is of the oil produced from callus however showed some variations in the quality of the oil, when compared with the oil obtained by hydro distillation of fungal infected agarwood. GC/MS analys is has shown the presence of about 32 different compounds comprising of furano-monoterpenoids, acids, alcohols and aldehydes, out of which about 15 compounds could be identified. About $30 \%$ of the identified compounds showed similarity with the original agarwood oil. More such studies are needed to characterise and compare oil production capacity of calli and respective oil quality. The effect of fungal impregnation on callus and agar oil production may be another field of research which is required. Therefore, the present studies initially aimed to standardize an efficient, rapid and less expensive protocol for the production of callus tissue in vitro and study of salient features and growth parameters of callus tissues of A. malaccensis Lam., so obtained that may be utilised for essential oil production in future.

\section{Materials and Methods}

Leaf tissues from 3-6 month old seedlings of $A$. malaccensis Lam. were used as explants for callus induction. Explants were surface sterilized as per modified method of De[13] with a few drops of Tween-20 for 15 minute followed by thorough washing (3-4 times) with distilled water followed by with sterile distilled water. Further steps were done under complete aseptic conditions using a laminar air flow cabinet. The explants were then treated with $70 \%$ ethanol for 1 minute, with $5-10 \%(\mathrm{v} / \mathrm{v})$ sodium hypochlorite solution for 15 minutes and finally washed with sterile distilled water for 3-4 times to remove the traces of chemicals. Different hormonal comb inations were tested at their varying concentrations ranging from $0-10 \mathrm{mg} / 12,4$ -Dichlorophenoxyacetic acid $(2,4-\mathrm{D})+0-,3 \mathrm{mg} / 1$ Kinetin $(\mathrm{Kn}), 0.5-4 \mathrm{mg} / 1$ 6-benzy ladenine purine (BAP) $+0.5-4 \mathrm{mg} / 1$ $\alpha$-naphthalene acetic acid (NAA) and 0-10mg/1 2,4 Dichlorophenoxyacetic acid (2,4-D) + 0.5-4mg/1 6-benzy ladenine purine (BAP) for callus induction in $A$. malaccensis (Table 1). One concentration from each combination that had given the highest bio mass of callus was selected for comparative studies. The surface sterilized explants were placed on MS medium[14] supplemented with different concentrations \& combinations of plant growth regulators at varying sucrose concentrations $(2-5 \% \mathrm{w} / \mathrm{v})$ to check their effect on callus induction, growth and development[12]. The three combinations i.e. 2,4-D (2 mg/l) $+\mathrm{Kn}(0.1 \mathrm{mg} / \mathrm{l})$, BAP $(0.5 \mathrm{mg} / \mathrm{l})+\mathrm{NAA}(3 \mathrm{mg} / \mathrm{l})$ and $2,4-\mathrm{D}$ $(2 \mathrm{mg} / \mathrm{l})+\operatorname{BAP}(0.5 \mathrm{mg} / \mathrm{l})$ were tested and represented as combination $\mathrm{A}$, combination $\mathrm{B}$ and combination $\mathrm{C}$ respectively. The $\mathrm{pH}$ of the medium was adjusted at 5.7 to 5.8 with the help of $\mathrm{NaOH}$ or $\mathrm{HCl}$ prior to adding $0.8 \%$ bacto agar and autoclaved at $121^{\circ} \mathrm{C}$ for 20 minutes. All the cultures were inoculated in 5 replicates and incubated at $25^{\circ} \pm 2^{\circ} \mathrm{C}$ in complete dark condition. A set of flasks were also kept in light illumination (light intensity ranging from $20-40 \mu \mathrm{E} / \mathrm{m}^{2}$ $\left.{ }^{\prime} S^{1}\right)$ to check the effect of light on callus growth. The percentage of callus bio mass on fresh weight (FW) and dry weight (DW) basis was recorded after the period of 15-30, 45-60 and 75-90 days respectively. Dry we ights were taken to check the mo isture contents (data not shown) in young and mature callus tissues. The morphological and microscopic features of Aquilaria callus were also studied as per the method prescribed by Deka[15].

\section{Results and Discussion}

In this paper, the emphasis was given on induction of callus in medicinally important tree species A. malaccensis Lam. using leaf explants. The induction and growth characteristics of Aquilaria callus from leaves, shoot tips and stem as explants were also reported earlier by Talukdar and Ahmed[16]. They have also obtained best callus using leaves as explants; hence, in the present studies, leaves were used for callus induction in this important tree species; however, present protocol was standardized at comparatively very reduced concentration of growth hormones. The results of our studies indicate that the optimum incubation period required is about 45-60 days in contrast to Talukdar and Ahmed[16] who obtained maximum callus in 45 days. This may be due to sub-culturing of callus in fresh medium by the investment of quite higher concentration of plant growth hormones. The hormone comb ination B i. e. BAP + NAA at 
the concentration of $0.5 \mathrm{mg} / 1 \& 3 \mathrm{mg} / 1$ respectively was found to be the best for fast callus induction and further proliferation in the test plant species (Table1). The MS med iu m supplemented with hormonal co mb ination $0.1 \mathrm{mg} / 1$ $\mathrm{NAA}+0.5 \mathrm{mg} / 1 \mathrm{BA}$ was also found suitable and gave the best result in the formation of protocorm-like bodies (PLB) obtained from shoot tips of Cymbidium species[17]. We as well recorded the $4 \%$ concentration of sucrose as most favourable in MS medium as standardized earlier by Talukdar and Ahmed[16] however; callus biomass at 3\% sucrose concentration was also considerably high some times highest $(7.231 \mathrm{~g}, 6.853 \mathrm{~g} \& 7.210 \mathrm{~g}$ in combination A. B \&C respectively) especially after 45-60 days of incubation. The dry cell biomass of callus was found to be proportional to their fresh cell biomass (Table1). In general, the callus growth declined in all treatments except in case of hormonal combination $\mathrm{C}$, where an increase in fresh to dry cell biomass ratio was noticed.

We recorded the highest callus bio mass in the MS medium supplemented with hormone combination B as $7.457 \mathrm{~g} \mathrm{FW}$ and $2.302 \mathrm{~g} \mathrm{DW}$ (Table 1) at optimum concentration of sucrose $(4 \%)$ after about 45-60 days of incubation. The lowest callus cell biomass was observed in hormones combination $\mathrm{C}$ at $2 \%$ sucrose concentration as $0.931 \mathrm{~g} \mathrm{FW}$ and $0.229 \mathrm{~g}$ DW callus cell biomass after same duration of incubation.

In hormone combination $\mathrm{A}$, the maximum callus bio mass was obtained (7.368g FW) in 45-60 days old culture at $4 \%$ sucrose concentration whereas the lowest was recorded with $2 \%$ sucrose $(1.661 \mathrm{~g} \mathrm{FW})$ concentration. In combination B, the maximum callus biomass $(7.457 \mathrm{~g})$ was obtained in $4 \%$ sucrose and the lowest was observed in $2 \%$ sucrose concentration $(0.493 \mathrm{~g})$ after $45-60$ days of incubation. Callus growth in hormone combination $\mathrm{C}$ depicted that $30 \%$ sucrose concentration supported the highest callus cell biomass
$(7.210 \mathrm{~g})$ and the lowest cell bio mass measured in case of $2 \%$ sucrose concentration (0.931g) after 45-60 days of incubation.

In 75-90 days incubation time, it was interesting to note that there was decrease in fresh cell biomass however, the dry cell bio mass increased. The reason might be due to the fact that lignification in callus tissues might have taken place as a result of cyto-differentiation in older callus tissues and made them harder (Figure1d). It was also evident by the changes in the colour and appearance of 75-90 days old callus which looked dull and darker.

Sucrose had various effects on callus initiation and growth (Figure 3). It is the most common source of carbohydrate needed in callus induction and regeneration of plants[18]. The induction of callus occurred comparatively earlier and its growth was recorded faster in case of media treated with $4 \%$ sucrose irrespective of hormonal treat ments up to 45-60 days of incubation (Figure 3C). The biomass of callus was universally proportional to the concentration of sucrose up to $4 \%$ and dec lined beyond it. From the present investigations, it was revealed that prolonged culturing period of callus has direct impact on its growth as weight of the callus declined sharply after 60 days of incubation. In contrast to the present findings, Talukdar and Ahmed[16] reported the highest growth of the callus on MS med iu msupplemented with quite higher a mount of gro wth hormones $(6 \mathrm{mg} / 1$ 2, $4 \mathrm{D}+2 \mathrm{mg} / 1$ $\mathrm{Kn}$ ) within 30 - 45 days of culture however concentration of sucrose was optimized as $4 \%$ which support our findings. In another experiment, the highest growth of Aquilaria agallocha callus (547.25\%) was obtained using $3 \%$ fructose as source of carbohydrate by keeping the hormonal treat ment constant through leaf explants after 45 days of culture[19]; however, the maltose $(60 \mathrm{~g} / \mathrm{l})$ did not supported callusing and showed the least growth rate $(212.76 \%)$ in fresh cell biomass.

Table 1. Effects of different growth hormones on biomass productionof A. malaccensisLam. in MS medium supplemented with different concentrat ions of sucrose, A represents 2, 4-D (2 mg/l) + Kn $(0.1 \mathrm{mg} / \mathrm{l})$; B represents BAP $(0.5 \mathrm{mg} / \mathrm{l})+\mathrm{NAA}(3 \mathrm{mg} / \mathrm{l}) ; \mathrm{C}$ represents $2,4-\mathrm{D}(2 \mathrm{mg} / \mathrm{l})+\mathrm{BAP}(0.5 \mathrm{mg} / \mathrm{l})$

\begin{tabular}{|c|c|c|c|c|c|c|c|}
\hline \multirow{3}{*}{$\begin{array}{c}\text { Hormone } \\
\text { Combination }\end{array}$} & \multirow{3}{*}{$\begin{array}{l}\text { Sucrose } \\
\text { (g) }\end{array}$} & \multicolumn{6}{|c|}{ Days of culture } \\
\hline & & \multicolumn{2}{|c|}{$15-30$} & \multicolumn{2}{|c|}{$45-60$} & \multicolumn{2}{|c|}{$75-90$} \\
\hline & & Fresh wt (g) & Dry wt (g) & Fresh wt (g) & Dry wt (g) & Fresh wt (g) & Dry wt (g) \\
\hline \multirow{4}{*}{ A } & 20 & 0.414 & 0.040 & 1.661 & 0.569 & 1.278 & 0.853 \\
\hline & 30 & 0.942 & 0.045 & 7.231 & 2.092 & 7.254 & 2.177 \\
\hline & 40 & 1.281 & 0.237 & 7.368 & 2.170 & 6.952 & 1.805 \\
\hline & 50 & 0.546 & 0.032 & 3.822 & 0.993 & 2.592 & 0.975 \\
\hline \multirow{4}{*}{ B } & 20 & 0.611 & 0.034 & 1.957 & 0.493 & 1.324 & 0.346 \\
\hline & 30 & 1.167 & 0.039 & 6.853 & 1.952 & 5.450 & 0.722 \\
\hline & 40 & 2.390 & 0.092 & 7.457 & 2.302 & 6.592 & 1.578 \\
\hline & 50 & 0.478 & 0.144 & 2.598 & 0.887 & 1.894 & 0.384 \\
\hline \multirow{4}{*}{$\mathrm{C}$} & 20 & 0.494 & 0.018 & 0.931 & 0.229 & 0.971 & 0.244 \\
\hline & 30 & 0.875 & 0.021 & 7.210 & 3.050 & 6.397 & 1.387 \\
\hline & 40 & 0.989 & 0.042 & 6.580 & 1.114 & 6.286 & 0.996 \\
\hline & 50 & 0.259 & 0.027 & 1.953 & 0.352 & 1.751 & 0.476 \\
\hline
\end{tabular}


From the present experiment, it can be concluded that after 45-60 days of incubation, hormonal comb ination $B$ and $4 \%$ sucrose were best options for rapid callus growth in $A$. malaccensis Lam. In all the treatments, $2 \%$ sucrose showed least growth $(0.931 \mathrm{gm})$ as compared to other sucrose concentrations (Figure 3A). In 15-30 days old callus, the highest growth was recorded in comb ination B $(2.390 \mathrm{~g} \mathrm{FW})$ followed by combination A (1.281g FW) and the lowest growth $(0.259 \mathrm{~g} \mathrm{FW})$ was observed in combination $\mathrm{C}$ in $4 \%$ sucrose (Figure 3C); but in 75-90 days old culture, callus in all treatments were declined except in hormone co mbination A with $3 \%$ (Figure $3 \mathrm{~B}$ ) sucrose and combination $\mathrm{C}$ with $2 \%$ sucrose (Figure3A) where the negligible amount of callus were increased. No clarification could be drawn for this. At $5 \%$ sucrose concentration, reduced growth of callus was recorded however; the highest growth was noted in the hormone combination A (Figure3D).

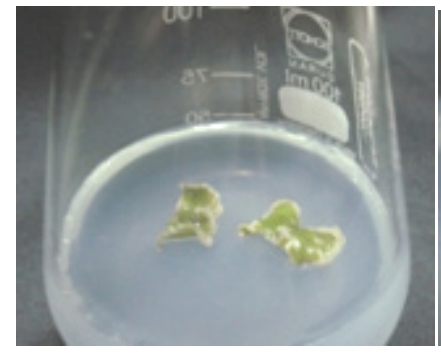

(a)

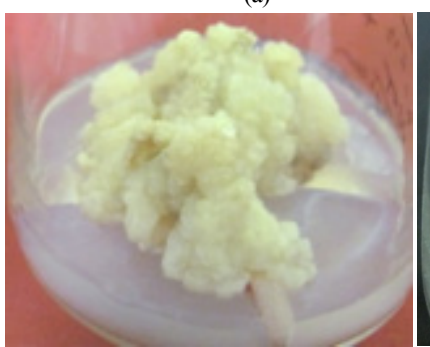

(c)

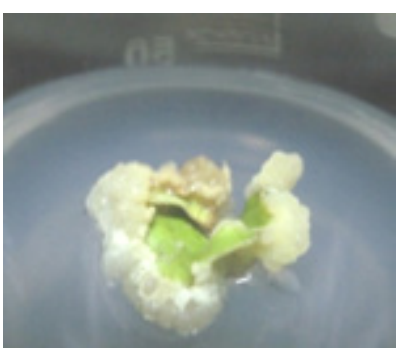

(b)

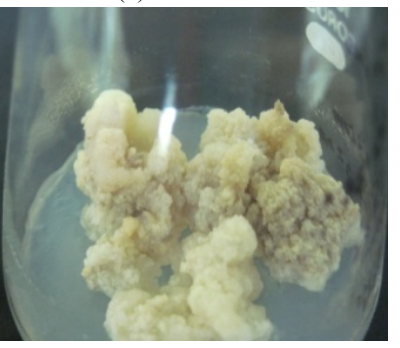

(d)
Figure 1. Stages of callus growth in A. malaccensis Lam.a. Initiation of callus, b\&c; Growth of the callus; d. Cell death

Callus tissues of $A$. malaccensis which were grown and maintained under dark become whitish or creamish yellow in colour (Figure $1 \mathrm{a}-\mathrm{c}$ ). They usually turned green when transferred under light illuminations (intensity $20-40 \mu \mathrm{E} / \mathrm{m}^{2}$ ${ }^{\prime} S^{1}$ ) due to development of chloroplastids. Aceto-carmine staining of young and matured callus tissues revealed the presence of embryogenic cells [15] which appeared crims on red in colour however non-embryogenic cells appeared unstained, distorted and irregular in shape or with lighter shade due to lack of protoplasm. Squash preparation of the callus tissue of $A$. malaccensis showed that the cellular composition was heterogeneous ranging from small cells with dense cytoplasm to large cells with vacuolated cytoplasm in case of young or friable callus. The friable callus cells were loose, with entire margin, full of protoplasm and mostly globular in shape with average diameter of $31.5 \mu \mathrm{m}$. The other shapes like oval, slightly elongated, beaked or co mma shaped ranging between 28-45 $\mu \mathrm{m}$ in length and $18-35 \mu \mathrm{m}$ in breath were also observed (Figure 2).

Oil extraction from callus of agarwood had successfully been done earlier[12] and reported that the oil has about $30 \%$ similarities with that of agar oil extracted from natural wood. In Taxus baccata L. Washingtonii, the valuable "Taxol", an anticancer agent is being extracted from callus tissues [20]. As the A. malaccensis is valued for agar oil, the mass callus production shows great promises to extract essential oil directly in future without sacrificing the whole tree.

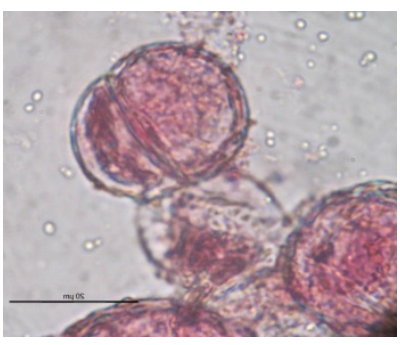

(a)

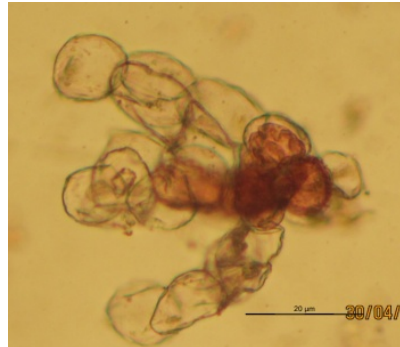

(c)

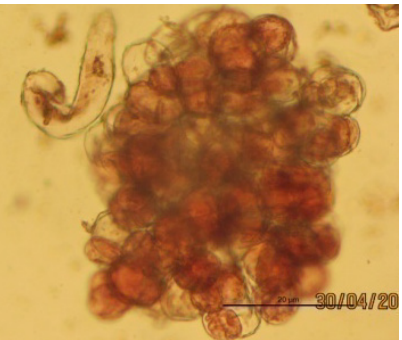

(e)

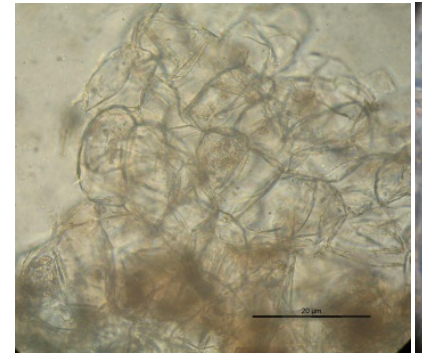

(g)

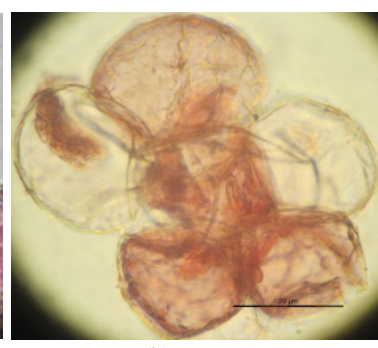

(b)

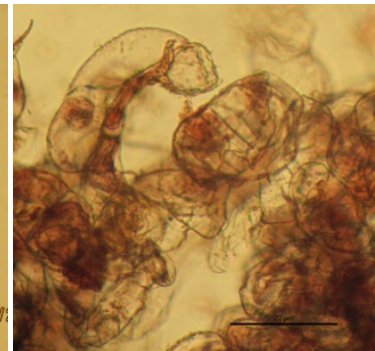

(d)

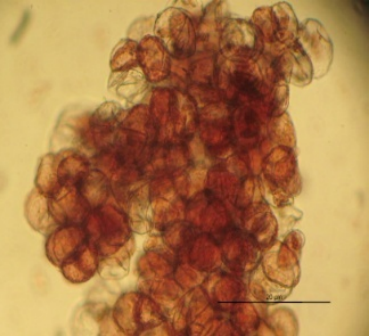

(f)

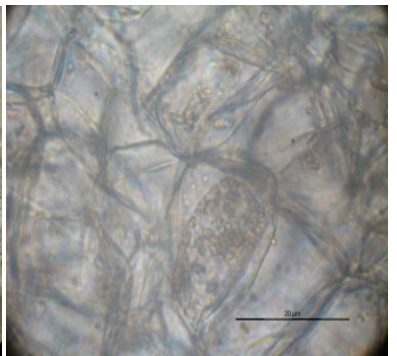

(h)
Figure 2. Callus tissues of A. malaccensis Lam. a-f. Embryogeniccells ofvarious shapes; g-h. Non-embryogeniccells; Scale Bar: $\mathrm{a}-\mathrm{h}=20 \mu \mathrm{m}$ 


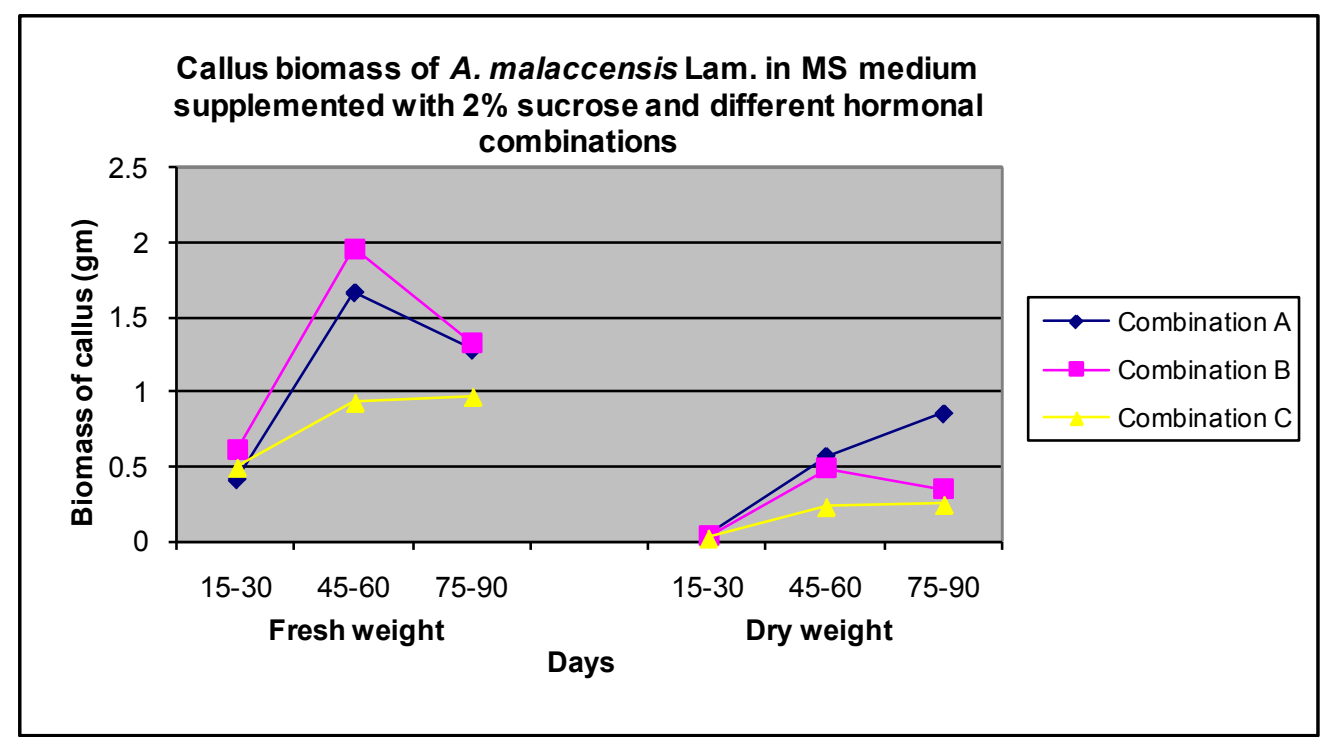

$\mathbf{A}$

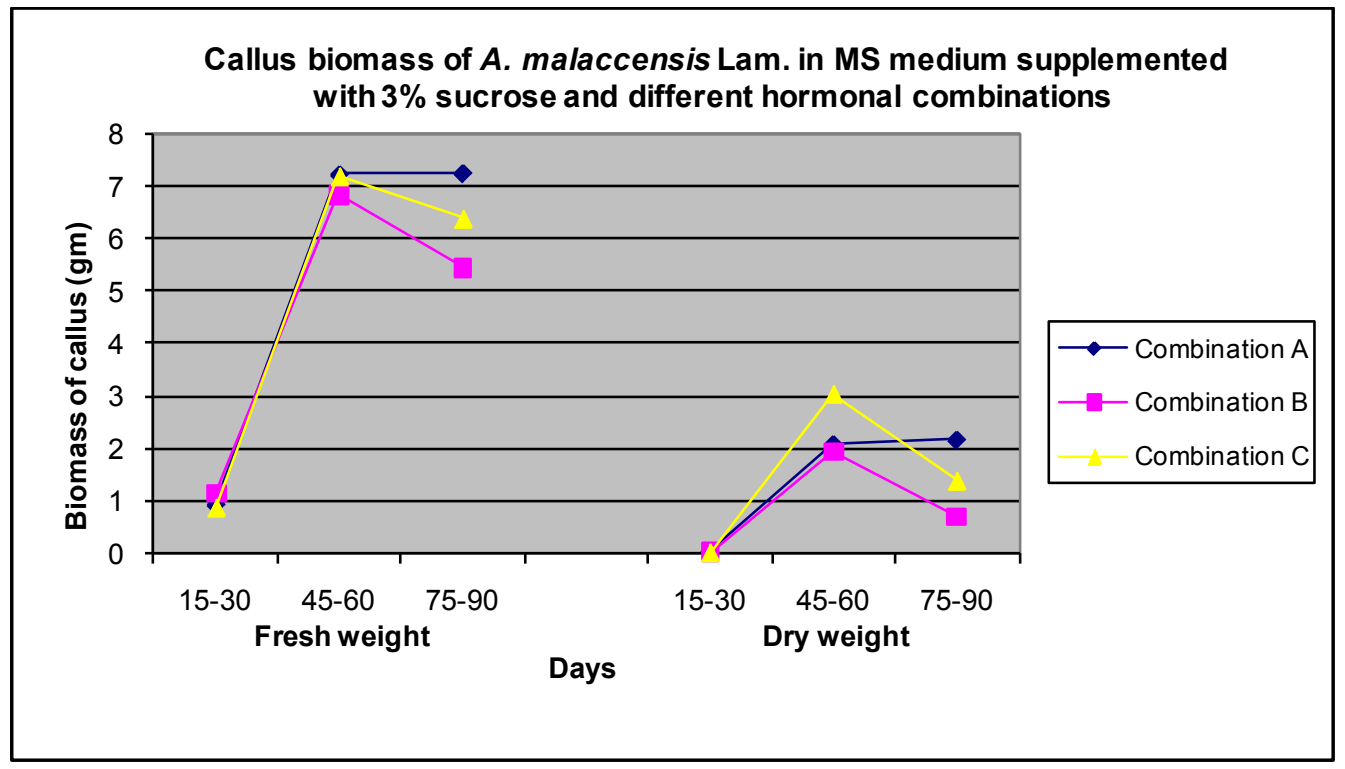

B

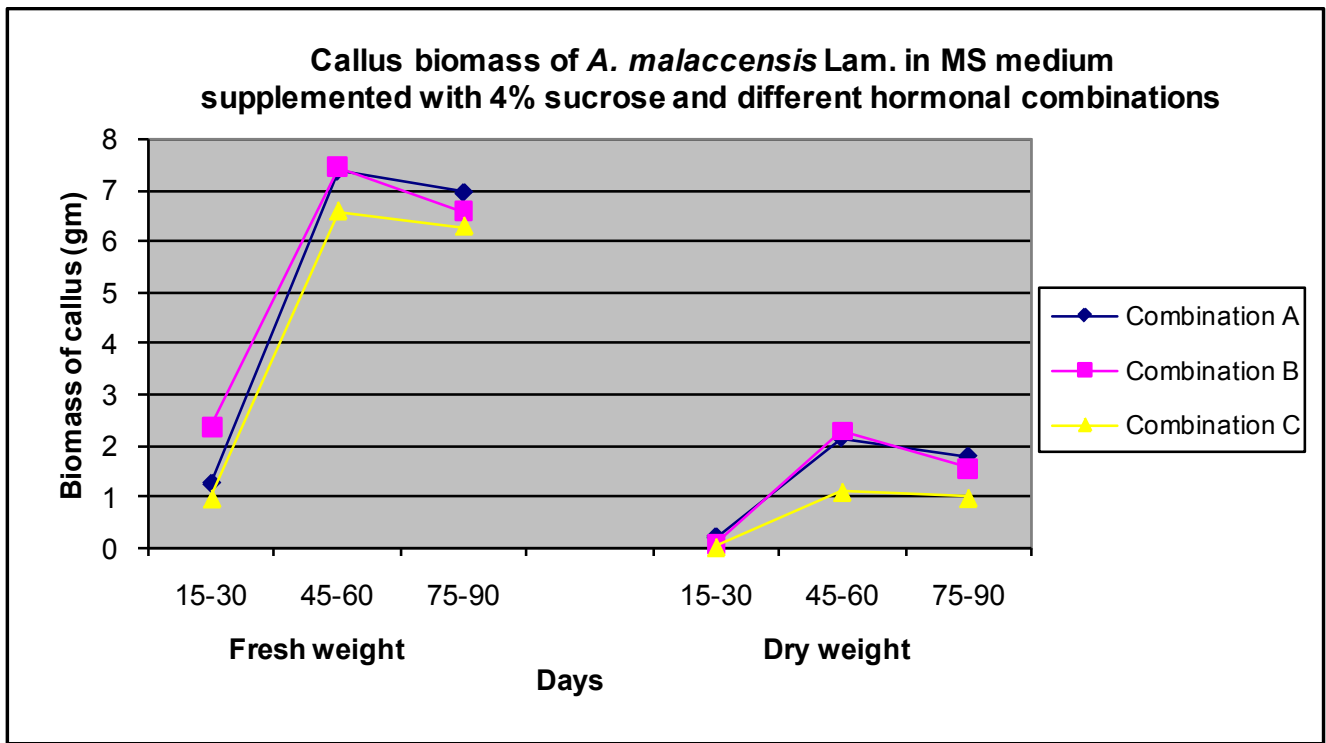

C 


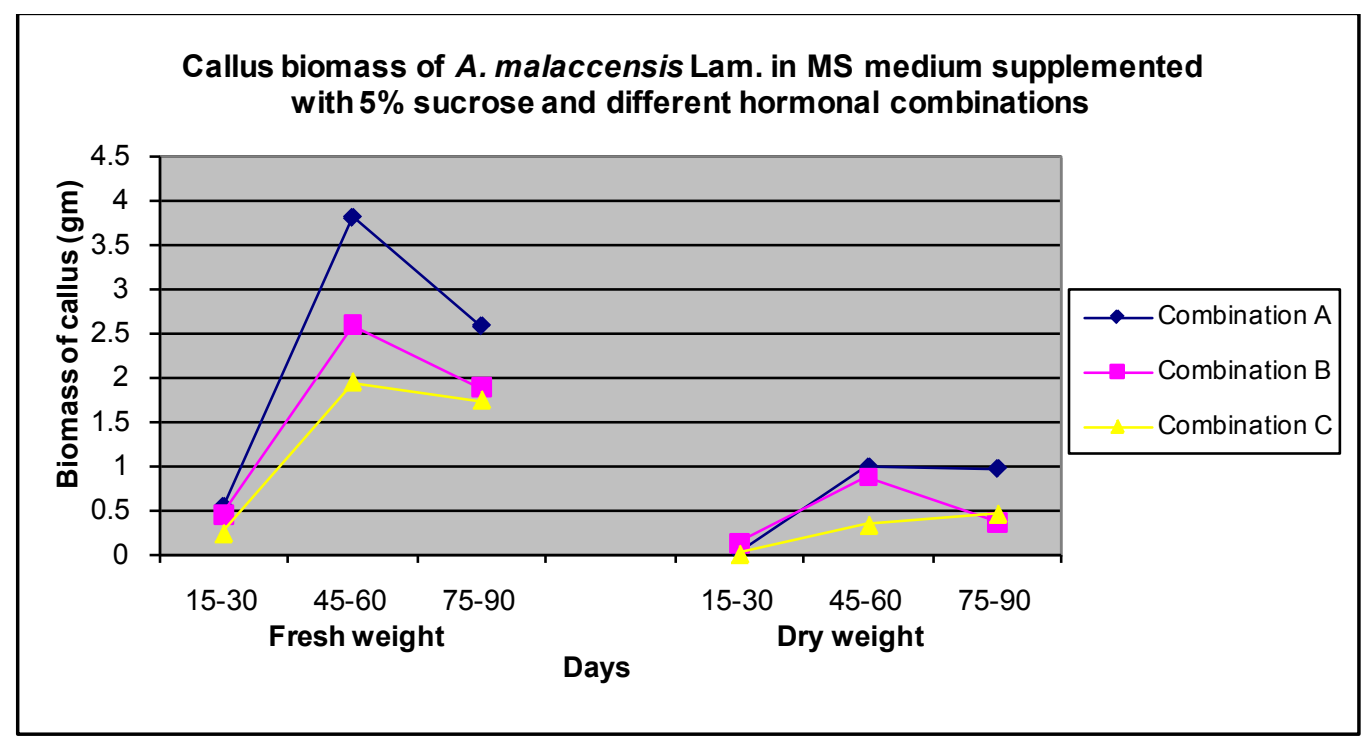

D

Figure 3. Callus biomass of A. malaccensis Lam. in MS medium withdifferent hormonalcombinations. A. $2 \%$ sucrose concentration; B. $3 \%$ sucrose concentration C. $4 \%$ sucrose concentration, D. $5 \%$ sucrose concentration

\section{Conclusions}

From the present investigations, a reproducible, standard and efficient tissue culture protocol for callus production using leaf explants in A. malaccensis Lam. has been defined which has importance from point of view of use of very less hormonal concentrations. MS medium supplemented with $\operatorname{BAP}(0.5 \mathrm{mg} / \mathrm{l})+\mathrm{NAA}(3 \mathrm{mg} / \mathrm{l})$ at $4 \%$ sucrose concentration was found the best for obtaining maximum callus biomass in agar species. Overall, combination A was found more suitable in terms of callus biomass at 3-5\% sucrose concentrations as compare to others. As the tree is economically important for preparation of perfumes, incense and traditional medicines, the present investigations may be helpful for large scale production of callus biomass and to oil traders for synthes is of agar oil from it. Another interesting area of research may be to investigate effect of introduction of endophytic fungi in it and its effect on agar oil quality and quantity analys is.

\section{ACKNOWLEDGMENTS}

We thank All India Council Technical Education, Government of India, New Delhi for providing financial support in carrying out this research work and Head, Department of Forestry, NERIST for providing lab and adminis trative facilities.

\section{REFERENCES}

[1] K Shrivastava, K Anuradha, T Tasso, "The role of fungi in the production of aromatic Agarwood in Aquilariaagallocha (Roxb.), A commercially important medicinal tree species of Arunachal Pradesh",Forest Biotechnology in India, S. A.
Ansari, C. Naray anan,andA. K. Mandal, Ed.Satish Serial Publishing House, Delhi,pp. 275-283,2008.

[2] L T Ng. YS Chang.AAKadir."A review on agar (gaharu) producing Aauilariasnecies".Publ. Forest research Institute Malaysia, Journal of Tropical Forest Product,vol. 2, no. 2, pp. 272-285,1997.

[3] S.Oldfield, C. Lusty, A. MacKinven, "The Word List of Threatened Trees", World Conservation Press, Cambridge, UK,pp. 650,1998.

[4] Online available: http://quin.unep-wcmc.org/trees/trade/aqu_ mal.htm.

[5] Anonymous, "The wealth of India, Raw material",Publication and information Directorate, New Delhi, vol. 1, pp. 88-90, 1948.

[6] HHeuveling van Beek, D Phillips, "Agarwood: Trade and CITES implementation in Southeast Asia", Unpublished report prepared for TRAFFIC Southeast Asia, Malay sia,1999.

[7] M LGupta, VMohankumar, K KJanardhanan, "Distribution of vesicular arbuscularmycorrhizae in some important medicinal and aromatic plants", KAVAKA,vol. 22/23, pp. 29-33, 1994-95.

[8] Online available: www.iucnred list.org.

[9] M Ahmed,PGogoi, "Germination behaviour and storage of seed and seedling vigour of AquilariaagallochaRoxb", in proceedings of seminar on scope \&dimension of Agar (Aquilaria spp.) plantation in NE region, pp. 28-33, 2000.

[10] MAnis, M Faisal, "In vitro regeneration and mass multiplication of Psoraleacorylifolia-an endangered medicinal plant",Indian journal of Biotechnology, vol. 4, pp. 261-264, 2005.

[11] D Uppendra, MSumit, JMeena, “Organogenesis, embryogenesis, and synthetic seed production in Arnebiaeuchroma-a critically endangered medicinal plant of the Himalaya",Pbl. Springer, In Vitro Cellular and Developmental Biology-Plant, vol. 41, pp. 244-248, 2005. 
[12] ATalukdar, G U Ahmed, S K Dutta, "In vitro produced agaroil from callus culture of AquilariaagallochaRoxb. and analysis of its chemical constituents by GCMS", Koryo, Terupenoyobi Seiyu Kagakunikansuru Toronkai Koen Yoshishu, vol.46, pp.350, 2002.

[13] K. K. De, An introduction to plant tissue culture. First Ed., Publ. New central book agency, Calcutta, May 1992.

[14] T Murashige, F Skoog, "A revised medium for rapid growth and bioassays with Tobacco tissue culture," Physiologia plantarum, vol. 15, pp. 473,1962.

[15] A C Deka,"Tissue culture studies of two species of (Piper betle and Piper longum) and establishment of plantlets in natural environment", Biotechnologythesis, Guwahati University, Guwahati, Assam, 2002.

[16] ATalukdar,G U Ahmed, "In vitro induction and growth characteristics of callus of AquilariaagallochaRoxb. from north-eastern region of India," Scientific Publishers,Asian J. of Microbial Biotechnology \&Environmental Science, vol. 3, no. 1-2,pp. 53-57, 2001.
[17] AABegum, MTamaki, SKako, "Formation of protocorm-like bodies (PLB) and shoot development through in-vitro culture of outer tissue of Cymbidium PLB",J. Japan. Soc. Hort. Sci.,vol.63, no. 3, pp. 663-673, 1994.

[18] M.R. Thompson,T. A.Thrope,"Metabolic and non-metabolic roles of Carbohydrates", Cell and Tissue Culture in Forestry, vol. 1, J.M. Bonga, and D.J. Durzan, Ed. MartinusNijhoffPublications, The Haque, pp. 89-112, 1987.

[19] ATalukdar, G U Ahmed, "Effect of sugars on the growth of callus in AquilariaagallochaRoxb. (Thymeliaceae)", in proceedings of the National Academy of Sciences India Section B (Biological Sciences), vol.74, pp. 85-90, 2004.

[20] SMihaljevic, IBjedov, MKovac, LLevanic, SJelaska, "Effect of explant source and growth regulators on in vitro callus growth of Taxusbaccata L. washingtonii",Food Technology and Biotechnology, vol. 40, no. 4, pp. 299-303, 2002. 